\title{
Future medical doctors need to be informed about CAM to ensure safe and competent patient care
}

\author{
C. Witt, B. Brinkhaus, S.N. Willich
}

Complementary and Alternative Medicine (CAM) remains a controversial topic. Despite its widespread use by patients, ${ }^{1}$ its provision by a large number of physicians and substantial student interest, ${ }^{2-3}$ it is rarely taught by medical schools in Europe. By contrast, in the United States (US) 82 medical schools have included CAM-related content in their compulsory curriculum $^{3}$ and special educational methods are used to teach about CAM. ${ }^{5}$

In a discussion on the teaching of CAM at universities, it is important to clarify which methods are designated by the term CAM. CAM covers a broad variety of treatment methods that are not part of conventional medicine (http://nccam.nih. gov/health/whatiscam/ and http://www. nhsdirectory.org/default.aspx? page= HLReport). These methods comprise whole medical systems, such as naturopathy, Chinese medicine and homeopathy, as well as single interventions such as aromatherapy. ${ }^{16}$ The National Centre for Complementary and Alternative Medicine (NCCAM) in the US defines whole medical systems as systems that are built upon complete systems of theory and practice. Such systems have evolved prior to and separate from conventional medicine (http://nccam.nih.gov/health/whatis cam/overview.htm).

Although survey data show that decision-makers at German medical schools are indeed interested in CAM, CAM is integrated in medical curricula to a very limited extent only. ${ }^{7}$ This is underscored by the fact that all chairs in CAM at medical schools are endowed chairs. A possi-

ble explanation for this is that medical schools feel bound to scientific medicine and that scientific evidence for many CAM treatments is scarce. However, some universities have been involved in CAM research for many years and offer lectures on CAM. ${ }^{8-10}$

Since 2003, naturopathy treatments (German: Naturheilverfahren) have been included in the mainstream medical curriculum in Germany, but the number of teaching hours and the content taught varies greatly between universities. In Germany, naturopathy is defined as a combination of lifestyle medicine and mind-body medicine (German: Ordnungstherapie), hydrotherapy, herbal medicine, exercise therapy and dietetic treatment. It is used either as a preventive measure or therapeutically. It depends on the university whether naturopathy alone is taught or whether other CAM treatments, such as homeopathy and Chinese medicine, are also included in the curriculum. In addition some universities offer optional courses on complementary medicine. In the spring of 2009, a conference on CAM education in German Universities was organized by the Carstens Foundation, offering a platform for discussion about experiences, cooperation and standardization in relation to CAM courses.

In Switzerland and Austria CAM is not included in the core medical curriculum. Lectures are mainly optional and depend on initiatives of individual universities. At Vienna medical school, for example, a lecture series on the fundamentals and the 
practice of CAM is offered by the Institute of General Medicine. Additional, more specialized, courses are offered in homeopathy, acupuncture and hypnosis. All medical students at Vienna medical school have to attend a compulsory casebased course on interdisciplinary patient management and this course addresses treatment options from both conventional medicine and CAM (e.g. homeopathy, osteopathy, herbal medicine, acupuncture, neural therapy). Another example is the medical school of Graz in Styria, which offers an optional lecture series in CAM with the main focus on homeopathy. In Switzerland, at the medical schools of Bern and Zürich, several courses are taught including lectures and practical courses in naturopathy, homeopathy, Chinese medicine, anthroposophical medicine and neural therapy. Most of these courses are offered as electives for interested students and they are run by the Kollegiale Instanz Komplementärmedizin (KIKOM) in Bern and by the Institute of Naturopathy of the Medical Department in Zurich.

Also in the Netherlands CAM courses are offered: a CAM elective at the University of Utrecht and a CAM course at the University of Nijmegen.

An interesting aspect in relation to CAM education is when CAM should be scheduled in the medical curriculum. The influence of CAM courses on the attitudes and empathic abilities of students has been discussed in the literature. ${ }^{11-16}$

A sound education is the predominant aim of medical schools. This raises the following question: should medical school exclusively teach evidence-based content? We agree that lectures at medical schools should be mainly based on scientific knowledge, but we argue that this should also include descriptive data and information. CAM has a special role in view of the huge gap between its high usage among the population and the paucity of scientific data. This can partly be explained by historical developments and by the fact that the most commonly used CAM treatments have been available for a longer period than modern clinical research. Nevertheless, the high usage of CAM in the population justifies our claim that future medical doctors should be informed about CAM. Every second patient has had experience with CAM and, without knowledge of CAM, medical doctors are not aware of possible interactions between CAM and conventional treatments. Additionally, future doctors need to be competent to guide their patients through the complex and seemingly overloaded CAM market. This does not imply, however, that they have to provide CAM treatment in their own practice.

The primary aim of CAM lectures at universities should therefore be 1) an introduction to the most commonly used CAM methods (e.g. naturopathy, homeopathy and acupuncture) to give students a deeper understanding of what CAM entails. Case conferences could be an interesting didactic approach for this purpose, ${ }^{17} 2$ 2) a summary of the current evidence for CAM based on usage, efficacy, effectiveness ${ }^{10}$ and safety. However as evidence is rapidly changing it makes little sense to focus on current research results only. Instead, the overall aim of CAM lectures should be to inform future medical doctors about CAM and stimulate critical appraisal of CAM treatments, using the best evidence available. Teaching about CAM also fits with a marked movement in the US and Europe towards a more integrative medical approach ${ }^{18}$ (http://www.imconsortium.org).

In our opinion, if medical schools refuse to teach their students basic knowledge and critical reflection about CAM, 
they are depriving their medical students of the ability to provide competent and safe patient care in the future.

\section{References}

1. Härtel U, Volger E. Inanspruchnahme und Akzeptanz klassischer Naturheilverfahren und alternativer Heilmethoden in Deutschland - Ergebnisse einer repräsentativen Bevölkerungsstudie. Forsch Komplementärmed 2004;11(6):327-334. [Consideration and acceptance of traditional naturopathy and complementary and alternative medicine in Germany - Results of a representative population study. Research in Complementary Medicine].

2. Furnham A, McGill C. Medical students' attitudes about complementary and alternative medicine. $\mathrm{J}$ Altern Complement Med 2003;9(2):275-284.

3. Lie D, Boker J. Development and validation of the CAM Health Belief Questionnaire (CHBQ) and CAM use and attitudes amongst medical students. BMC Med Educ 2004;4:2.

4. Barzansky B, Jonas HS, Etzel SI. Educational programs in US medical schools, 1999-2000. JAMA 2000;284(9):1114-1120.

5. Wetzel MS, Kaptchuk TJ, Haramati A, Eisenberg DM. Complementary and alternative medical therapies: implications for medical education. Ann Intern Med 2003;138(3):191-196.

6. Witt CM. Komplementärmedizin: Weitere Forschung ist die Basis für Integration in die Versorgung. Dtsch Arztebl. 2009;1056:A1786-A1789. [Complementary medicine: further research is the basis for integration in health care. German Medical Journal].

7. Brinkhaus B, Joos S, Lindner M, Kohnen R, Witt C, Willich SN et al. Integration of Complementary and Alternative Medicine into German Medical School Curricula - Contradictions between the Opinions of Decision Makers and the Status Quo. Forsch Komplementarmed Klass Naturheilkd 2005;12(3):139-143.

8. Ostermann T, Brinkhaus B, Melchart D. [University Forum Workshop for Natural Medical Treatment and Complementary Medicine]. Forsch Komplementarmed 1999;6(1):41-42.

9. Weidenhammer W. Forschung zu Naturheilverfahren und Komplementärmedizin: Luxus oder Notwendigkeit? Dtsch Arztebl 2006;103:A2929/B-2551/C-2453. [Research into naturopathy and complementary medicine: luxury or necessity? German Medical Journal].
10. Witt CM, Linde K. The need for CAM research training. Forsch Komplementmed 2008;15(2):6970.

11. Frenkel M, Ben Arye E. The growing need to teach about complementary and alternative medicine: questions and challenges. Acad Med 2001;76(9):251-254.

12. Sikand A, Laken M. Pediatricians' experience with and attitudes toward complementary/ alternative medicine. Arch Pediatr Adolesc Med 1998;152(11):1059-1064.

13. Greenfield SM, Brown R, Dawlatly SL, Reynolds JA, Roberts S, Dawlatly RJ. Gender differences among medical students in attitudes to learning about complementary and alternative medicine. Complement Ther Med 2006;14(3):207-212.

14. Duggan K, Verhoef MJ, Hilsden RJ. First year medical students and complementary medicine. Ann R Coll Physician Surg Can 1999;32:157-160.

15. Owen DK, Lewith G, Stephens CR. Can doctors respond to patients' increasing interest in complementary and alternative medicine? BMJ 2001;322(7279):154-158.

16. Owen D, Lewith GT. Complementary and alternative medicine (CAM) in the undergraduate medical curriculum: the Southampton experience. Med Educ 2001;35(1):73-77.

17. Scheffer C, Edelhäuser F, Tauschel D, Hahn EG. Symposium Fallkonferenz Integrative Medizin: Vorbild für das Medizinstudium? GMS Z Med Ausbild. 2007;24(1):Doc05. Zugänglich unter: http://www.egms.de/de/journals/zma/200724/zma000299.shtml. [Case conference on Integrative Medicine: example for medical education? Autumn issue of the German Journal of Medical Education].

18. Willich SN. Editorial. EUJIM. 2009;1:163-164.

\section{The authors:}

Prof. dr. C. Witt, B. Brinkhaus, S.N. Willich, Institute for Social Medicine, Epidemiology, and Health Economics, Charité University Medical Center, 10098 Berlin, Germany.

\section{Correspondence}

Prof. dr. Claudia Witt, Institute for Social Medicine, Epidemiology, and Health Economics, Charité University Medical Center, 10098 Berlin, Germany. Tel: +49-30-450529002; Fax: +49-30-450529902.

E-mail: claudia.witt@charite.de

No potential conflict of interest relevant to this article was reported 